\title{
Dampak Corona Virus-19 (Covid-19) Terhadap Perekonomian Masyarakat Kelurahan Ule Kecamatan Asakota
}

\author{
Rafiuddin ${ }^{1^{*}}$, Ismail $^{2}$, Muhammad Sya'aban ${ }^{3}$ \\ 1,2,3) Institut Agama Islam Muhammadiyah Bima \\ *Corresponding Author:d_bulan22@yahoo.com
}

\begin{abstract}
ABSTRAK - Penelitian ini adalah penelitan kualitatif dengan mengambil data primer dan data sekunder berkaitan dengan UMKM di tempat penelitian. Adapun teknik pengumpulan data meliputi observasi, wawancara, dan dokumentasi. Teknik analisis data mencakup pengumpulan data, reduksi data, penyajian data dan penarikan kesimpulan dengan cara menggunakan data-data yang berhubungan dengan dampak Covid-19 terhadap perekonomian masyarakat kelurahan Ule kecematan Asakota. Dari hasil wawancara dan pembahasan dapat disimpulkan bahwasannya pandemi Corona Virus-19 (Covid19) berdampak pada perekonomian masyarakat. Dampak-dampak tersebut, pertama, pendapatan dan penghasilan menurun. Kedua, adanya kelangkaan dan kenaikan harga barang sehingga tidak efektifnya pendapatan para pelaku UMKM yang ada pada pedagang atau bakulan atau jenis usaha lainnya.
\end{abstract}

Kata Kunci - Covid-19; UMKM

\section{PENDAHULUAN}

Lahirnya Covid-19 telah merubah perekonomian dunia, termasuk Indonesia dibuktikan adanya pengalihan-pengalihan anggaran dalam rangka penangananya, termasuk di desa-desa. Penemuan Covid-19 disematkan World Health Organization (WHO) untuk coronavirus disease that was discoverd in 2019 pada tanggal 11 Februari 2020, dengan sebutan Covid-19 memiliki dampak yang sangat luar biasa di seluruh dunia tidak ketinggalan juga dengan desa-desa yang ada di Indonesia. Desa-sesa terpengaruh terutama dalam bidang ekonomi dan pembangunan yang selama ini banyak mengandalkan bantuan dari pusat. Berbagai macam kebijakan telah dibuat oleh pemerintah Indonesia dalam menangani kasus covid-19 ini Pemerintah harus memilih kebijakan dari jalur 2 arah dalam menangani pandemik ini.

Pemerintah harus melihat kebijakan pencegahan (substantive) dan memfokuskan pada kebijakan yang mengatur perekonomian. Kedua kebijakan tersebut dilakukan secara bersamaan yang menyebabkan tidak efektifnya implementasi dari kebijakan tersebut. Ketahanan ekonomi masyarakat akan dapat dicapai melalui strategi modal sosial. Modal sosial merupakan seperangkat nilai atau norma yang dibawa oleh anggota kelompok di dalam komunitas yang memungkinkan kerjasama diantara mereka. Modal sosial 
memberikan kekuatan masyarakat dalam menghadapi kondisi sulit melalui implementasi norma-norma kolektif yang dapat menumbuhkan kepercayaan diantara anggota masyarakat sehingga jaringan sosial bisa terbentuk.

Dalam situasi pandemi ini, menurut Kemenkop UKM terdapat sekitar 37.000 UMKM yang memberikan laporan bahwa mereka terdampak sangat serius dengan adanya pandemi ini ditandai dengan: sekitar 56 persen melaporkan terjadi penurunan penjualan, 22 persen melaporkan permasalahan pada aspek pembiayaan, 15 persen melaporkan pada masalah distribusi barang, dan 4 persen melaporkan kesulitan mendapatkan bahan baku mentah. Masalahmasalah diatas juga semakin meluas jika dikaitkan dengan adanya kebijakan Pembatasan Sosial Berskala Besar (PSBB) yang diterapkan di beberapa wilayah di Indonesia. Merujuk pada Peraturan Menteri Kesehatan No. 9 tahun 2020 tentang Pedoman PSBB dalam rangka Percepatan Penanganan COVID-19, PSBB meliputi pembatasan kegiatan tertentu penduduk dalam suatu wilayah yang diduga terinfeksi COVID-19 termasuk pembatasan terhadap pergerakan orang dan/atau barang untuk satu provinsi atau kabupaten/kota tertentu untuk mencegah penyebaran COVID-19. Pembatasan tersebut paling sedikit dilakukan melalui peliburan sekolah dan tempat kerja, pembatasan kegiatan keagamaan, dan/atau pembatasan kegiatan di tempat atau fasilitas umum. ${ }^{1}$

Adapun beberapa pertanyaan yang sesuai judul yang di angkat oleh si peneliti yaitu dampak Corona Virus - 19 (covid-19) terhadap perekonomian masyarakat Kelurahan Ule Kecamatan Asakota. Beberapa fakta lapangan hasil observasi awal peneliti dampak Corona Virus (covid-19) sangatlah berpengaruh bagi masyarakat Kelurahan Ule apalagi di tinjau terhadap perekonomian semacam usaha mikro kecil menengah (UMKM) dan juga para usaha sekitar wilayah tersebut seperti bengkel atau pun kaum buruh, tetapi di sini si peneliti hanya turun di dua tempat seperti usaha dagang dan juga bengkel andika motor yang dimana sesuai responden menyatakan Corona Virus (covid-19) sangatlah berpengaruh apalagi di tinjau terhadap konsumen yang kurang mengunjungi pengusaha, ditambah lagi dengan kelangkaan barang dengan kenaikan barang yang akan berimbas pada perekonomian masyarakat baik itu pada penjual maupun pada konsumen itu sendiri. ${ }^{2}$ Dari hasil survei awal yang dilakukan oleh peneliti, banyak dari masyarakat yang mengeluhkan hasil pendapatan yang berkurang akibat mewabahnya virus covid-19, maka dari itu peneliti tertarik

1 Betty Silfia Ayu Utami." Dampak Pandemi Covid 19 Terhadap Sektor UMKM di Indonesia", Jurnal Bidang Ekonomi Dan Kebijakan Publik, Vol. 03, No. 1, Juni 2021

2 Siti Rahmawaty," (wawancara)" Di Gudang Pupuk Kelurahan Ule, Pada Tanggal 30 Maret 2021, Jam 15.32 WITA 
untuk mengangkat judul "Dampak Corona Virus-19 (Covid-19) Terhadap Perekonomian Masyarakat Kelurahan Ule Kecamatan Asakota".

\section{TINJAUAN PUSTAKA \\ Corona Virus-19 (Covid-19) \\ Pengertian}

Covid-19 merupakan wabah penyakit jenis mutasi baru gabungan dari virus sars dan mers yang pertama kali muncul di kota Wuhan negara China yang menyebar ke seluruh penjuru dunia. Kata covid-19 sendiri merupakan kepanjangan dari Corona Virus Diseases yang muncul pada tahun 2019 (Covid19). Corona Virus merupakan virus RNA strain tunggal positif. Berkapsul dan tidak bersegmen. ${ }^{3}$

\section{Bahaya Corona Virus (Covid-19)}

Kasus Covid-19 yang serius dapat berkembang menjadi pneumonia berat, ARDS dan kegagalan beberapa organ yang bisa menyebabkan kematian, sedangkan kasus tidak parah menunjukkan gejala biasa infeksi sistem pernapasan.

World Health Organization mengumumkan pandemi pada 11 Maret 2020. Pandemi Covid-19 telah menyebar dengan cepat lebih dari 17.660.523 kasus dengan 680.894 kematian yang mempengaruhi 260 negara hingga Agustus 2020. Situasi Covid-19 di Indonesia kurang lebih 130.718 kasus positif dengan 85.798 kasus sembuh dan 5.903 kematian hingga Agustus 2020 yang telah menyebar di 34 provinsi di Indonesia. Penderita Covid-19 terbanyak berada di DKI Jakarta (26.624 kasus), Jawa Timur (25.917 kasus), Jawa Tengah (10.765 kasus) (WHO, 2020; BNPB, 2020). ${ }^{4}$

\section{Perekonomian Masyarakat Pengertian Ekonomi}

Menurut para ahli, perkataan "ekonomi" berasal dari bahasa yunani, yaitu "eicos" dan "nomos" yang berarti rumah, dan nomos yang berarti aturan. Jadi, ekonomi ialah aturan-aturan yang menyelenggarakan kebutuhan hidup manusia dalam rumah tangga, baik dalam rumah tangga rakyat (volkshuishouding) maupun dalam rumah tangga negara (staatshuishouding). ${ }^{5}$

\section{Usaha Mikro Kecil Menengah (UMKM)}

3Yuliana, "Corona Virus diseases (covid-19); sebuah tinjauan literstur", jurnal wellness and healthy magazine, vol. 2 (1), february 2020, 187 - 192

4Rara Julia Timbara Harahap, “ Karakteristik Klinis Penyakit Corona Virus 2019”, Jurnal Penelitian Perawat Profesional, Vol. 2 (3), Agustus 2020, 1 - 2

5K.H. Abdullah Zaky Al Kaaf, “Ekonomi Dalam Perspektif Islam”, Penerbit Pustaka Setia Bandung, 1 Maret 2002, 18-19

J-ESA (Jurnal Ekonomi Syariah) 
UMKM memiliki pengertian yang cukup beragam. Dewan Koperasi Indonesia (DEKOPIN) memberikan pengertian tentang UMKM sebagai para pelaku usaha ekonomi yang sering dikategorikan sebagai perusahaan yang berskala kecil, menggunakan teknologi tradisional, dan dikelola secara sederhana.

UMKM memiliki peran yang sangat penting dan strategis dalam perekonomian, khususnya pada negara-negara berkembang. UMKM yang memiliki badan hukum formal dapat berkontribusi hingga 60 persen dalam membuka lapangan pekerjaan dan 40 persen dalam pembentukan Produk Domestik Bruto (PDB). Jumlah ini akan jauh lebih besar jika UMKM dalam bentuk informal juga dihitung. ${ }^{6}$

\section{Permasalahan UMKM}

1. Tantangan UMKM

Lingkungan ekonomi internasional di saat ini dan mendatang berubah sangat cepat. Dengan dikembangkannya Teknologi Informasi (TI), seperti internet, CD-rom, komunikasi satelit, maka informasi dari satu negara ke negara lain dalam sekejab dapat berpindah. Dampak dari percepatan informasi ini, dapat dirasakan dalam kehidupan ekonomi, keuangan, dan jasa telekomunikasi.

Dengan demikian, melalui TI usaha bisnis lebih berpeluang meningkatkan daya saing sekaligus memenangkan persaingan yang semakin ketat. Persoalannya, masih sedikit UMKM yang memanfaatkan TI. Menurut Eko Wahyudi (Direktur Pembinaan Koperasi dan UMKM Bappenas), menyatakan bahwa dari 245 ribu unit UMKM potensial di Indonesia, hanya $12 \%$ saja yang sudah memanfaatkan TI. Lemahnya akses terhadap TI mengakibatkan banyak peluang bisnis tidak bias dimanfaatkan. Hal ini membawa sejumlah tantangan bagi pengembangan UMKM, yaitu salah satunya adalah Semakin ketatnya persaingan pasar domestik. Produk UMKM akan semakin bersaing dengan produk luar negeri. Pesaing luar negeri relative memiliki keunggulan dalam manajemen, penguasaan teknologi, sumberdaya manusia, keuangan, akses pasar, dan akses lainnya.

2. Kendala Pengembangan UMKM

Masalah yang masih krusial dihadapi oleh UMKM di antaranya adalah masih rendahnya permodalan. UMKM masih menghadapi kendala dalam menambah permodalan, baik untuk modal kerjamaupun modal investasi. Dalam hal ini terdapat keengganan pihak perbankkan dalam memberikan kredit kepada UMKM. Untuk membantu permodalan bagi

"Sony Hendra Permana," Strategi Peningkatan Usaha Mikro, Kecil, Dan Menengah (Umkm) Di Indonesia", Jurnal Strategy Of Enhancement, Juni 2017, 95-96 
UMKM ini pemerintah telah mewajibkan kepada perbankan untuk menyalurkan Kredit Usaha Rakyat (KUR). KUR ditujukan untuk memperluas akses kredit Perbankan bagi UMKM yang produktif, layak namun belum bankable. Kesulitan dalam masalah permodalan, membawa ke masalah mendasar yang mempengaruhi proses inovasi dan transformasi UMKM, berimbas pula pada kesulitan dalam pemasaran terutama dari segi pengenalan pasar, penentuan harga, negosiasi, serta jalur distribusi dan penjualan.

Kendala lain yang cukup krusial adalah kesulitan bahan baku, terutama UMKM di sektor processing, dan manufacturing. Hal ini dapat terjadi akibat minimnya modal kerja sehingga semua transaksi harus dilaksanakan dalam bentuk uang tunai. Misalnya pengusaha garmen kesulitan untuk memperoleh benang atau pengusaha kecap kesulitan bahan baku kedelai, karena sedikitnya penawaran atau kalau ada harganya relatif mahal. dihasilkan menjadi statis dan tidak mampu lagi untuk bersaing di pasar. ${ }^{7}$

\section{METEDOLOGI PENELITIAN}

Dalam penelitian ini, peneliti menggunakan pendekatan penelitan yang bersifat Kualitatif. Penelitian kualitatif merupakan cara dalam melakukan penelitian yang berdasarkan pada fakta empiris dan apa yang dialami responden. ${ }^{8}$ Sumber datanya yaitu data primer dan data sekunder dengan teknik pengumpulan datanya meliputi wawancara, dokumentasi, dan observasi. Adapun instrument yang digunakan dalam penelitan ini adalah sebagai berikut: 1) pedoman observasi, 2) pedoman wawancara 3) format dokumentasi.

\section{HASIL PENELITIAN DAN PEMBAHASAN}

\section{Penyajian Data Dan Analisis Data}

Bagaimana dampak perekonomian masyarakat Kelurahan Ule akibat Corona Virus (Covid-19)

Bedasarkan hasil wawancara yang dilakukan oleh peneliti ialah kepada respoden di Kelurahan Ule Kecematan Asakota Kota Bima yaitu bapak Bayu salah satu pemilik bengkel beliau mengatakan bahwa:

“Di masa pandemi covid-19 saat ini menjadikan dampak cukup mengurangi pemasukan setiap hari dikarenakan pelaggang kurang berkunjung di bengkel berbeda dengan sebelum covid. Sebelum covid pemasukan Alhamdulillah lancar. Tidak hanya disitu juga, covid juga

7 Hartono."Faktor-Faktor Yang Mempengaruhi Perkembangan UMKM Di Surakarta". Jurnal Bisnis Dan Manajemen. Vol. 14, No. 1, 2014. 19-20.

8 Ahmad Usman, M. Si, “Mari Belajar Meneliti”, (Jakarta: Granata Press 2009), 225. 
memberikan dampak yang dimana kenaikkan harga barang seperti oli dan lainnya." 9

Dari hasil wawancara di atas peneliti menyimpulkan bahwa Corona Virus (covid-19) memberikan dampak dari pendapatan bapak Bayu dan juga kenaikkan harga barang dari salah satu yang mempunyai bengkel yang nama bengkelnya ialah "Andika Motor". Selain dari Bapak Bayu peneliti juga mewawancarai salah satu responden yang ada di kampung Songgela yang bernama ibu Ratna, ia menyatakan bahwa :

“Kalau untuk sekarang tidak ada pengaruh karena memang pendapatan selalu lancar karna konsumennya bukan saja orang dalam kampung melainkan orang wisatawan yang berdatangan dalam kunjungan di pantai wisata yang berada di Kelurahan Kolo. Terkecuali pada waktu Pembatasan Sosial Berskala Besar (PSBB) yang dimana jalur Kelurahan Ule menuju jalur Kelurahan Kolo di tutup dengan portal dengan penjaga sangat ketat sehingga para wisatawan yang berkunjung akan di pulangkan. Dari situlah pendapatan kita disini berkurang karena pendapatan lebih besar ada pada para wisatawan yang berkunjungan."10

Dalam hal ini, para pelaku pedagang/usaha yang berada di wilayah kampung songgela omset yang lebih banyak didapatkan ada pada para wisatawan yang berkunjung dan terjadinya pembatasan sosial berskala besar (PSBB) menghambat pendapatan atau omset yang lebih tinggi.

\section{Pembahasan}

Usaha mikro, kecil dan menengah adalah salah satu bagian penting dari perekonomian suatu bangsa. Sehingga perlu dukungan dari berbagai kalangan seperti Sumber Daya Manusia (SDM) sebagai pelaku penguat UMKM. Karena peran pentingnya tersebut pemerintah terus melakukan upaya mengembangkan usaha mikro, kecil dan menengah (UMKM). ${ }^{11}$

Salah satunya UMKM di Kelurahan Ule Kecamatan Asakota Kota Bima yang mana UMKM ini, beroperasi sebagai pedagang mikro kecil, contoh : kios, bengkel, bakulan dan lain lain. Serta dengan adanya kebijakan dari pemerintah mengenai isolasi atau karantina, penutupan jalan membuat konsumen membutuhkan waktu lumayan lama untuk sampai ke lokasi toko dan jam oprasional toko usaha berubah-ubah.

Adapun barang yang dibutuhkan oleh pedagang atau bakulan susah di dapat atau mengenai pendapatan UMKM tersebut tidak normal seperti biasa

\footnotetext{
${ }^{9}$ Bayu, Wawancara, Ditempat Bengkel, Pada Tanggal 21 Juli 2021, 15.39

10 Ratna, Wawancara, Ditempat Kediaman, Pada Tanggal 30 Agustus 2021, 16.05

${ }^{11 E v i ~ S u r y a n i, ~ " A n a l i s i s ~ D a m p a k ~ C o v i d-19 ~ T e r h a d a p ~ U M K M ", ~ J u r n a l ~ I n o v a s i ~ P e n e l i t i a n, ~ V o l . ~ 1, ~ N o . ~}$ 1, Januari 2021
} 
dikarenaka covid-19 dan juga kelangkaan barang yang dijual di sebabkan kurangnya output barang pada pertokoan yang sumber pencarian para pedagang atau bakulan tersebut.

Adapun hasil temuan dan penelitian terhadap dampak Covid-19 di kelurahan Ule di perkuat oleh hasil temuan yang dilakukan oleh Betty Silfia Ayu Utami dalam jurnalnya berkaitan dengan covid terhadap UMKM dan ia uraikan bahwa pada aspek konsumsi dan daya beli masyarakat, pandemi ini menyebabkan banyak tenaga kerja berkurang atau bahkan kehilangan pendapatannya sehingga berpengaruh pada tingkat konsumsi dan daya beli masyarakat terutama mereka yang ada dalam kategori pekerja informal dan pekerja harian. Sebagian besar masyarakat sangat berhati-hati mengatur pengeluaran keuangannya karena ketidakpastian kapan pandemi ini akan berakhir. Hal ini menyebabkan turunnya daya beli masyaraka akan barangbarang konsumsi dan memberikan tekanan pada sisi produsen dan penjual. ${ }^{12}$

Adapun hasil temuan dari jurnalnya Rais Agil Bahtiar yang penelitiannya dalam wilayah Jabodetabek yang berkaitan dengan dampaknya Covid-19 terhadap UMKM dan ia uraikan bahwa berdasarkan hasil survei Katadata Insight Center (KIC) yang dilakukan terhadap 206 pelaku UMKM di Jabodetabek, mayoritas UMKM sebesar 82,9\% merasakan dampak negatif dari pandemi ini dan hanya 5,9\% yang mengalami pertumbuhan positif. Kondisi Pandemi ini bahkan menyebabkan 63,9\% dari UMKM yang terdampak mengalami penurunan omzet lebih dari 30\%. Hanya 3,8\% UMKM yang mengalami peningkatan omzet. ${ }^{13}$

\section{PENUTUP}

Dari hasil wawancara dan pembahasan dapat disimpulkan bahwasannya pandemi Corona Virus-19 (Covid-19) berdampak pada perekonomian masyarakat. Dampak-dampak tersebut, pertama, pendapatan dan penghasilan menurun. Kedua, adanya kelangkaan dan kenaikan harga barang sehingga tidak efektifnya pendapatan para pelaku UMKM yang ada pada pedagang atau bakulan atau sejenis usaha lainnya.

\section{DAFTAR PUSTAKA}

Betty Silfia Ayu Utami." Dampak Pandemi Covid 19 Terhadap Sektor UMKM di Indonesia", Jurnal Bidang Ekonomi Dan Kebijakan Publik, Vol. 03, No. 1, Juni 2021

12 Betty Silfia Ayu Utami," Dampak Pandemi Covid 19 Terhadap Sektor UMKM di Indonesia", Jurnal Bidang Ekonomi Dan Kebijakan Publik, Vol. 03, No. 1, Juni 2021.

13 Rais Agil Bahtiar,"Dampak Pandemi Covid-19 Terhadap Sektor Usaha Mikro, Kecil, Dan Menengah Serta Solusinya", Jurnal Bidang Ekonomi Dan Kebijakan Publik, Vol. 13, No. 10, Mei 2021, 20.

J-ESA (Jurnal Ekonomi Syariah) 
Siti Rahmawaty," (wawancara)" Di Gudang Pupuk Kelurahan Ule, Pada Tanggal 30 Maret 2021, Jam 15.32 WITA

Yuliana, "Corona Virus diseases (covid-19); sebuah tinjauan literstur", jurnal wellness and healthy magazine, vol. 2 (1), february 2020, 187 - 192

Rara Julia Timbara Harahap, " Karakteristik Klinis Penyakit Corona Virus 2019”, Jurnal Penelitian Perawat Profesional, Vol. 2 (3), Agustus 2020, 1 - 2

K.H. Abdullah Zaky Al Kaaf, "Ekonomi Dalam Perspektif Islam", Penerbit Pustaka Setia Bandung, 1 Maret 2002, 18-19

Sony Hendra Permana," Strategi Peningkatan Usaha Mikro, Kecil, Dan Menengah (Umkm) Di Indonesia", Jurnal Strategy Of Enhancement, Juni 2017, 95-96

Hartono."Faktor-Faktor Yang Mempengaruhi Perkembangan UMKM Di Surakarta". Jurnal Bisnis Dan Manajemen. Vol. 14, No. 1, 2014. 19-20.

Ahmad Usman, M. Si, "Mari Belajar Meneliti”, (Jakarta: Granata Press 2009), 225.

Nahyar Munkar, S.Pdi (Kepala Kelurahan Ule), Wawancara Pada Tanggal 27 juli 2021, 10.30

Bayu, Wawancara, Ditempat Bengkel, Pada Tanggal 21 Juli 2021, 15.39

Ratna, Wawancara, Ditempat Kediaman, Pada Tanggal 30 Agustus 2021, 16.05

Evi Suryani, "Analisis Dampak Covid-19 Terhadap UMKM", Jurnal Inovasi Penelitian, Vol. 1, No. 1, Januari 2021

Betty Silfia Ayu Utami," Dampak Pandemi Covid 19 Terhadap Sektor UMKM di Indonesia",Jurnal Bidang Ekonomi Dan Kebijakan Publik, Vol. 03, No. 1, Juni 2021.

Rais Agil Bahtiar,"Dampak Pandemi Covid-19 Terhadap Sektor Usaha Mikro, Kecil, Dan Menengah Serta Solusinya", Jurnal Bidang Ekonomi Dan Kebijakan Publik, Vol. 13, No. 10, Mei 2021, 20. 